\title{
The Role of Faith in Developing Community Civilization
}

\author{
Associate Professor Dr Engku Ahmad Zaki Engku Alwi \\ Faculty of Islamic Contemporary Studies, Universiti Sultan Zainal Abidin, Gong Badak Campus \\ 21300 Kuala Terengganu, Terengganu, Malaysia \\ Email: drkuzaki@unisza.edu.my \\ Roose Nilawati Subki \\ Academy of Language Studies, Universiti Teknologi MARA Kuantan Campus, \\ Jalan Tanjung Api, 25050 Kuantan, Pahang, Malaysia \\ Email: roosensubki@pahang.uitm.edu.my \\ Nor Aini Abu Bakar \\ Academy of Language Studies, Universiti Teknologi MARA Kuantan Campus, \\ Jalan Tanjung Api, 25050 Kuantan, Pahang, Malaysia \\ Email: noraini_abakar@pahang.uitm.edu.my
}

Doi:10.5901/mjss.2014.v5n23p1608

\begin{abstract}
This paper hopes to highlight the role of faith in ensuring social stability with reference to Al-Quran and to prove that faith is the determining agent of social stability of a community civilization. Thus, all parties responsible in developing the human capital and social stability towards achieving an excellent community civilization need to give emphasis on the aspects of faith.
\end{abstract}

Keywords: Role of Faith, peacefulness, social stability, community civilization

\section{Introduction}

Al-Quran al-Karim cites a lot of the ups and downs stories of past races or civilizations to give knowledge and education to the Muslims. What is most fascinating is that some of those stories are repeated many times in different Surahs to further strengthen and emphasize the elements of teachings so that they can be applied in the reality of life which is very challenging nowadays. The stories of the Saba', the 'Ad, the Thamud communities, for instance, are bits of nostalgia of the past that reveal their own hidden secrets that can only be understood by Muslims who think.

The stories presented in Al-Quran urge the Muslims to understand, study and analyze human history and mannerisms which are essential elements in human civilization that can strengthen their faith and awareness about their existence on this earth created by Allah (s.w.t). Besides that, an invaluable lesson that can be learnt from traces of those historical stories is the essential role of faith in determining the direction and the rise and fall of any civilization.

Based on the importance of faith in civilization development, this paper hopes to disclose the history and mannerisms of people in the past revealed by Allah (s.w.t) in al-Quran to serve as lessons and examples for Muslims today in the process of developing a superb civilization. This is consistent with Allah's (s.w.t) demand in al-Quran when He says:

Many patterns of behavior have passed before you. So, traverse the land and see what was the fate of those who rejected (the prophets). This is a declaration for mankind, and guidance, and a lesson for the God-fearing. (Surah Al EImran, verses 137-138)

Thus, the rise and fall of any civilization depends on the faith of the people. This is because faith is the key to success, prosperity, behavior and happiness here on this earth and in akhirat. 


\section{Definition}

Based on the title mentioned above, there are four essential elements in this paper, namely, faith, peacefulness, social and community.

Faith means a bond or a knot that is strongly and properly tied (Abu al-Husayn Ahmad b. Faris b. Zakariyya 1991 90). When faith is matched with Islam, it means a form of belief and understanding that must be held tight and steady so that it remains steadfast in the heart and does not shatter, no matter what challenges may appear (Muhammad b. Ibrahim al-Hamd 1998 10).

In other words, faith refers to a very strong, deep and sincere conviction of love and affection solely for Allah (s.w.t) surpassing whatever else in this world. Hence, faith towards Allah (s.w.t) encompasses Tauhid Rububiyyah and Tauhid Uluhiyyah that regard Allah as the Creator and the great Administrator of the whole universe.

Peacefulness, according to Kamus Dewan (2002 1208), means peaceful, quiet/calm, free from disasters, violence, troubles etc. Peacefulness is Allah's (s.w.t) blessing to those who submit to Him. This is evident from the al-Quran when Allah (s.w.t) relates the story of the Saba' community: There was indeed a sign for (the community of) Saba' in their home-land: two gardens, (one) on the right and (one) on the left. "Eat of the provision from your Lord, and be grateful to Him - (You have) an excellent city, and a Most-Forgiving Lord." (Surah Saba', verse 15)

From the above verse, it is clear that Allah (s.w.t) permits activities that can benefit mankind and can help the community to progress, develop and prosper in various aspects of life, so long as they comply with the syariat of Islam. At the same time, Muslims must acknowledge the fact that everything comes from Allah (s.w.t). For that, Muslims must always show their gratitude for His bountiful blessings. This gratitude is one of the characteristics of spiritual development that needs to be present in a person's heart in this dynamic world (Wahbah al-Zuhayli 1991, vol.21-22 169-170).

According to Kamus Dewan, social means everything that is related to society and societal matters (Kamus Dewan 2002 1301).

Community means a group of people joined together, out of their own free will or dictated by others, due to certain special obligations towards religion, residential area or time period they live in (Al-Asfahani, Al-Husayn b. Muhammad alRaghib t.t. 86).

\section{The Role of Faith in Developing Community Civilization}

In al-Quran Allah (s.w.t) cites a lot of past community civilizations, from civilizations that were prosperous and peaceful based on strong religious beliefs and devotions to Allah (s.w.t) such as the one developed by Prophet Sulayman a.s. and Dhulqarnayn, to civilizations built by the 'Ad, Thamud, Saba', Fir'aun and Namrud races who defied Allah (s.w.t).

Al-Quran stresses that the success of any civilization or community depends on whether the people are faithful and honest in their devotion to Allah (s.w.t), and perform good deeds as stipulated by Allah's (s.w.t) syariat (Abdul Hadi Awang 2005 157).

Al-Quran also reveals true accounts of ruined civilizations. These will remain as historical evidence. Even though the civilizations achieved great material successes, the communities that became proud of their achievements turned against Allah (s.w.t). Their destructive behaviors and reckless attitudes diminished their faith towards Allah (s.w.t) (Abdul Hadi Awang 2005 159).

Al-Quran highlights past civilizations that were built by people with great skills and knowledge in various fields that helped boost superb social development and success, yet were eventually destroyed due to their defiance of Allah (s.w.t).

For instance, Allah (s.w.t) says: Have they not traveled through the earth and seen how was the fate of those who used to be before them? They were stronger than these in power and in traces left on the earth, but Allah seized them because of their sins. There was no one to save them from Allah. That was because messengers used to come to them with clear signs, but they disbelieved. Then, Allah seized them. Surely, He is Strong, severe in punishment (Surah Ghafir, verses 21-22).

When discussing these verses, Dr. Wahbah al-Zuhayli appeals to those who deny the teachings of Prophet Muhammad (s.a.w), to travel around the earth created by Allah (s.w.t) to witness the destruction of the past non-believers who denied the teachings of their prophets. As a result, severe pain, suffering and humiliation befell them, whereas at that time they were known to be very strong, powerful and successful nation with beautiful castles, strong forts to ward enemies away, great towns and superb civilization. However, Allah (s.w.t) destroyed them because of their sins and defiance (Wahbah al-Zuhayli 1991, jil.23-24 100). 
In Surah al-Ankabut, Allah (s.w.t) says: And (We destroyed) 'Ad and Thamud, and it is visible to you through their dwellings. And the Satan had beautified for them their deeds, so he prevented them from the (right) way, even though they were people of insight. And (We also destroyed) Qarun and Pharaoh and Haman. Indeed Musa came to them with clear signs; so they acted arrogantly on the earth, and were not (able) to escape. Thus We seized each one of them for his sin. So to some of them We sent a violent wind; and some of them were seized by a Cry; and some of them We made to sink in the earth; and some of them We drowned. And Allah was not to do injustice to them, but they used to do injustice to their own selves. (Surah al-'Ankabut, verses 38-40)

Based on the above verses, Dr. Wahbah al-Zuhayli concludes that the reasons and causes of destruction, pain and suffering of all people of the past are similar. They completely defied Allah (s.w.t) and destroyed the earth with their cruel acts, sins and wrongdoings (Wahbah al-Zuhayli 1991, jil 19-20 241).

Al-Quran explains in great detail the types of abusive and destructive acts done by people of the past that caused the destruction of their civilization. Some of these acts involved being cruel, believing in taghut, creating harm and damage, doing sinful acts and wrongdoings, being proud of status and wealth, having poor akhlak and not appreciating Allah's (s.w.t) blessings. All these wrongful deeds clearly depict that the society at that time was facing a huge threat on their faith. Their faith crisis was evident from their defiant behavior towards their prophets.

A lot of people today are experiencing similar faith crisis as those people of the past. Because of this, criminal acts are being done rampantly all over the world. Any criminal act is created by a trust system which is fragile and misleading that may lead to a paradigm shift or distorted view of the world. This may result in negative value foundation which will eventually create negative attitude and behavior that lead to criminal activities (Pahrol Mohamad Juoi 2003 71).

Involvement in horrifying crimes such as fornication, baby dumping, child rape, robbery, breach of trust, alcohol drinking committed by some Muslims shows that they deny the existence of the angels, the heaven and the hell in the hereafter. It is ridiculous to claim that these offenders are not aware that Islam prohibits these crimes because they grow up and live in an Islamic community that does not condone to such behaviors. The only possible explanation why some Muslims still carry out these immoral and sinful acts is they are facing a very serious crisis in believing in Allah (s.w.t), and this can eventually threaten and destroy their faith. They are neither scared of the horrendous Hellfire nor attracted with the offer to enter the divine Heaven. This is an example of faith crisis that befalls the Muslim community nowadays due to dysfunctional faith education process (Zakaria Stapa 1999 136-137).

The scenario above depicts Muslims' attitudes and way of life (past and present) that ignore the functions and elements of Islam in their everyday activities. In other words, Islam is no longer seen as the backbone of every life activity. This situation is consistent with the idea stated by Prof. Syed Hussein Nasr (1975 118):

"One often sees women who dress in the latest European fashions and try to act like Western women but who at the same time, display completely traditional religious attitude at moment of stress or sorrow or on religious occasions. Likewise, many men who present a rationalistic front indifferent to religion become totally transformed in holy places or pilgrimage or at moments of participation in religious ceremonies."

It is evident from al-Quran that Allah (s.w.t) promises the believers excellent, powerful, prosperous, stable and successful life, provided they fulfil the first condition that is, being faithful to Him. In regard to this, Allah (s.w.t) says: Allah has promised those of you who believe and do good deeds that He will certainly make them (His) vicegerents in the land, and He made those before them, and will certainly establish for them their religion which He has chosen for them, and will certainly give them peace in place of fear in which they were before; (provided that) they worship Me, ascribing no partner to Me. And those who turn infidel after that are the transgressors. (Surah al-Nur, verse 55)

This verse highlights the characteristics of a successful devout nation that upholds both faith only to Allah (s.w.t) and righteous deeds in life. Thus, Allah (s.w.t) fulfils His promise by granting the Muslims the glory and power on this earth, the victory against the non-believers so that Islam remains as the only religion blessed by Allah (s.w.t) (Wahbah alZuhayli 1991, jil. 17-18 286).

The real strength and vital energy of a Muslim or a Muslim community are not in the wealth or property, but in how they believe in Allah (s.w.t) and do good deeds. Wealth or property is just a tool to achieve something. The strength of a Muslim community is not measured based on the number of people. It is useless if the figure is big but the souls of the people are empty. People may think that the real strength is standing with a weapon in their hands. However, it is still not considered the real strength if the person holding the weapon does not have a purpose for it (Hamka t.t.218).

It is imperative to have faith as the first condition in developing the Muslims. If Muslims are lagging behind in various areas of life, the main cause for this is their misconceptions and their deviations from the true teachings of Islam as well as their weakness of faith that is rooted in the hearts (Muhammad al-Sayyid Muhammad Yusuf 1997 41). 
Prof. Yusuf al-Qaradawi stresses this further when he says: I have said and I will still say that the key to Muslims' strength of character and the catalyst for their excellence is faith. It is faith that has propelled Muslims as the best people on this earth for the mankind, till they succeeded to achieve one victory after another over the great powers of that time, even when they were inadequate in terms of the number of troops and munitions of war (Yusuf al-Qaradawi 1985 21).

It is undeniable that faith does give a great impact on a Muslim's life. The effect of faith on a man and a woman can be seen from the conversion to Islam by Umar b. al-Khattab and Khansa. History has proven that with faith Muslims succeeded in building and developing the civilization of their community. It is no longer a secret that it is faith, and not anything else, that triggers positive changes and develops the Muslim community (Muhammad 'Abd Allah al-Khatib t.t. 21).

Allah (s.w.t) in Surah Ali 'Imran says: Do not lose heart and do not grieve, and you are the upper-most if you are believers (Surah Ali 'Imran, verse 139).

This verse is a clear signal that faith is the key requirement to achieve victory, excellence, glory and power on this earth. Allah's (s.w.t) promise will definitely come true if faith is clearly understood, appreciated and interpreted in the context of the reality of life of every Muslim.

Sa'id Hawwa points out that Muslims today are facing onslaughts from the West who reject Islam. The Western people have great sophisticated equipment, while the Muslims do not have such equipment as the enemy's. Therefore, if Muslims do not have the spiritual strength from the aspects of faith, Muslims will forever lose (Sa'id Hawwa 1984 46).

As such, faith is the most important weapon owned by Muslims to confront their enemies. Didn't Islamic historical records prove that the companions of Prophet Muhammad (s.a.w) and the earlier generations of Muslims fought to uphold Islam with very minimal war equipment and their number was small but they had very strong faith on Allah (s.w.t) when dealing with their enemies? What good are sophisticated weapons and equipment if there is no faith in the heart? (Muhammad 'Abd Allah al-Khatib t.t. 62).

Thus, with faith as a weapon, the Islamic generations of the past were able to move forward to eliminate the remnants of paganism and eventually they became noble people. Being noble leads to ultimate glory and is the true nature of a person who has faith and believes in Allah (s.w.t) (Muhammad Qutb 1989 47).

It is clear from the above facts that faith plays a vital role in developing a community civilization. This is because faith in Allah (s.w.t) will make every Muslim obey and submit to Allah's (s.w.t) perfect syariah. As a result of the perfect faith, Muslims will be able to meet their needs as humans in all aspects of life without being influenced by human desires and weaknesses.

Faith demands every member of the community to always worship only Allah (s.w.t), and never participate in all forms of shirk either openly or discreetly. In other words, every Muslim must understand the concept of life as a complete submission to Allah (s.w.t), the concept of a day's work as an act of worship, human beings as Allah's (s.w.t) caliphs to inhabit and glorify this earth and the duty to achieve strength and success in all fields of life as jihad.

Faith and piety to Allah (s.w.t) are the key to Allah's (s.w.t) innumerable blessings, while the idol worshipers or those involved in shirk are just going to destroy the reward of every good deed done. With respect to this, Allah (s.w.t) gives His warning: It has already been revealed to you and to those before you (that): If you associate (partners with Allah), your deeds shall be rendered useless, and you shall be among the losers. On the contrary, it is Allah whom you should worship; and be among the grateful (Surah al-Zumar, verses 65-66).

Faith can also be seen as the most important asset in creating awareness on the importance of religion and morality in the reality of contemporary life. The full confidence in Allah (s.w.t) and the true faith to Him, The All Seeing, The All Hearing and The All Knowing will spark an inner sense of guilt in a Muslim's heart if he defies Him and give him peace and tranquility if he obeys Him. By having true faith, the Muslim will eventually acquire a profound understanding and appreciation of Islam and in turn possess a noble personality to develop an exceptionally harmonious society.

A Muslim who has very strong faith and impeccable manners will never harm the harmony of his community because he realizes the fact that all his actions and movements are being observed and monitored by Allah (s.w.t), The All Seeing and The All Knowing. All criminal acts, corruption, prejudice, oppression and the like are rampant in a community due to lack of true faith.

Allah (s.w.t) says: If the people of the towns believed and feared Allah, We would have opened for them blessings from the heavens and the earth, but they disbelieved. So, We seized them because of what they used to earn for themselves (Surah al-A'raf, verse 96) 
The above verse, in general, means that a civilization stands tall when true faith, good deeds and impeccable manners remain steadfast in the lives of the people. On the other hand, if the community has severe crises of faith, of doing good and of good manners, then its civilization will be destroyed.

In a broader context, Islam is a religion that considers universal peace and welfare of the community. As such, Islam promotes the Muslims to collaborate and tolerate with one another to glorify their lives on the earth. This earth belongs to all beings created by Allah (s.w.t). It is not a property owned by any one race or nation. Everyone has equal rights to live on the earth and shares the responsibility in ensuring universal peace and success are achieved.

Therefore, Islam strongly prohibits any form of oppression, cruelty, or disputes among races of different faith and beliefs. Islam, as a religion of blessings for the entire universe, is testified by Allah (s.w.t): And We have not sent you but as mercy for all the worlds (Surah al-Anbia, verse 107)

Prophet Muhammad (s.a.w) is the best role model and example who managed to create an exceptionally diverse community of various groups namely Muslims, Jews, Christians and pagans to be united and lived harmoniously during his reign. On a number of occasions the Prophet visited sick people and the dead even though they were believers of other religions.

In fact, difference in faith did not cause hostility and fighting among races, yet they collaborated well with one another in ensuring Madinah developed successfully and peacefully in the economical, social, and defense sectors. This proves that different religions or beliefs are not major barriers towards a relationship that is united and harmonious among societies.

This is consistent with Allah's (s.w.t) statement in Surah al-Mumtahanah, verse 8: Allah does not forbid you as regards those who did not fight you on account of faith, and did not expel you from your homes, that you do good to them, and deal justly with them. Surely Allah loves those who maintain justice.

It is clear that Islam does not prohibit Muslims to hold intimate and diplomatic ties with other groups of people in aspects that bring good and benefits to people at large, so long as they do not resent Islam. At the same time, Islam demands Muslims to portray good, clean, honest, tolerant behavior and character when dealing with other races in the hope they realize the beauty of Islam and eventually open their hearts to embrace Allah's (s.w.t) religion.

Moreover, Muslims being Allah's (s.w.t) best creation, since the time of Prophet Muhammad (s.a.w) have upheld peace and blessings for the whole universe.

This simply means that Islam never insists Muslims to force the human race to accept Islam as their way of life. There is no compulsion in Islam, as mentioned by Allah (s.w.t) in Surah al-Baqarah, verse 256: There is no compulsion in Faith. The correct way has become distinct from the erroneous. Now, whoever rejects the Taghut (the Rebel, the Satan) and believes in Allah has a firm grasp on the strongest ring that never breaks. Allah is All-Hearing, All-Knowing.

This verse reveals that one of the foundations of Islam is the absence of compulsion. What needs to be done to draw people towards Islam is to give explanations and dakwah nicely and wisely, by providing outstanding examples of good deeds based on true teachings of Islam, and not through the use of violence or brutal repression.

This is the real secret of success of Prophet Muhammad's generation and the subsequent generations in developing a society of different races who are united and collaborative in facing life's challenges. This postmodern era and globalization without boundaries of the new millennium, have somewhat posed challenges for the Muslims, together with other people, to work hard to create a strong unity and excellence in various fields of life.

\section{Conclusion}

Islam as a religion that is syumul never prohibits its followers to strive for excellence in all fields of life. Every Muslim who is faithful to Allah (s.w.t) is expected to work hard to become successful or excellent in his life. In other words, Islam never reprimands its followers for achieving success. Living on this earth is a journey that everyone has to benefit from, through the process of worshiping and submitting himself to Allah (s.w.t) and by performing all his obligations in fardhu ain and kifayah in the most perfect, honest and transparent way.

People will not benefit from this world properly if they fail to observe and understand the reasons behind the creation of this earth for mankind as caliphs which are clearly highlighted by Allah (s.w.t) in the al-Quran and explained by Prophet Muhammad (s.a.w). Therefore, it is essential for every Muslim to equip himself with knowledge and skills in order to understand and benefit from this world as effectively as possible. In short, it is of the utmost importance for Muslims to understand Islam as a comprehensive system of their existence and apply Islam in their everyday lives in developing the desired civilization, in sya Allah. 


\section{References}

Abu al-Husayn Ahmad b. Faris b. Zakariyya (1991), Mu'jam Maqayis al-Lughah. 'Abd al-Salam Muhammad Harun (tah.), j. 4 , Beirut: Dar al-Jayl.

Muhammad b. Ibrahim al-Hamd (1998), 'Aqidah Ahl al-Sunnah wa al-Jama'ah. Riyad: Dar Ibn Khuzaymah.

Muhammad Syukri Salleh (1987), Pembangunan Berteraskan Islam. Petaling Jaya: Penerbit Fajar Bakti Sd. Bhd.

Kamus Dewan. 2002. Edisi Ketiga. Kuala Lumpur: Dewan Bahasa dan Pustaka.

Mohd. Nor Jusoh (2003), Tamadun Islam, Dungun: Politeknik Dungun Terengganu.

Al-Asfahani, Al-Husayn b. Muhammad al-Raghib (t.t.), Mufradat fi Gharib al-Qur'an. Dimasyq: Dar al-Qalam.

Abdul Hadi Awang (2005), Hadharah Islamiyyah Bukan Islam Hadhari. Kuala Lumpur: Nufair Street Sdn. Bhd..

Wahbah al-Zuhayli, Dr. (1991), Tafsir al-Munir. j. 23-24. Dimasyq: Dar al-Fikr.

Pahrol Mohamad Juoi (2003),"Kenapa Kita Masih Gagal Menangani Jenayah" dalam Minda, Edisi September 2003,

Zakaria Stapa (1999),"Proses Pendidikan Islam dan Ancaman Masa Kini" dalam Pemikir, bil. 17, Julai-September 1999,

Syed Hussein Nasr, Prof. (1975), Islam and The Plight of Modern Man, London: Longman.

Hamka, Prof. Dr., (t.t.), Tafsir al-Azhar, j. 18. Jakarta: Penerbit Pustaka Panjimas.

Muhammad al-Sayyid Muhammad Yusuf, (1997),al-Tamkin li al-Ummah al-Islamiyyah fi Daw' al-Qur'an al-Karim. Kaherah; Dar alSalam.

Yusuf al-Qaradawi, Prof. Dr. (1985), Ayna al-Khalal. Kaherah: Dar al-Sahwah li al-Nasyr.

Muhammad 'Abd Allah al-Khatib.(t.t.) Khasa'is al-Mujtama' al-Islami. Kaherah; Dar al-Tawzi' wa al-Nasyr al-Islamiyyah.

Sa'id Hawwa (1984), Kay La Namdi Ba'idan 'An Ihtiyajat al-'Asr, Kaherah: Dar al-Salam.

Muhammad Qutb, (1989), Hal Nahnu Muslimun, al-Sa'udiyyah: Mu'assasah al-Madinah. 